\title{
Fighting Wheat Stem Rust: Pathogenesis-Related Genes, From Conventional To Modern Approaches
}

\author{
Shazia Anwer Bukhari ${ }^{1}$, Shahzad Bashir ${ }^{1}$, Mahmood-ur-Rahman² and Makhlouf Bekhit ${ }^{3}$ \\ ${ }^{1}$ Department of Biochemistry, Government Collage University - Faisalabad, Allama Iqbal Road, \\ Faisalabad-38000, Pakistan \\ ${ }^{2}$ Department of Bioinformatics and Biotechnology, Government Collage University - Faisalabad, Allama \\ Iqbal Road, Faisalabad-38000, Pakistan \\ ${ }^{3}$ Department of Genetics and genetic engineering, Faculty of Agriculture, Benha University, Egypt \\ *Corresponding Author: makhlouf.bakhit@fagr.bu.edu.eg
}

\begin{abstract}
Stem rust is a major threat to wheat worldwide. It causes damage to almost $85 \%$ wheat varieties and may reduce the annual yield up to $20 \%$. It is caused by a pathogenic fungus Puccinia graminis. Many efforts are being carried out to eliminate this deadly disease but not successful due to less understood of disease mechanism at molecular level. Number of genes have been studied which are responsible for the disease but their interactions are not well known. In this review article, conventional and modern technologies to combat the stem rust pathogen are compared, and innovative approaches that make wheat resistant against evolving deadly strains of the pathogen are discussed.
\end{abstract}

Keywords: Stem rust, Triticum aestivum, Ug99, Puccinia graminis, PR genes, molecular approches

\section{Introduction}

Wheat (Triticum aestivum L.) is a staple food that meets almost $50 \%$ of the total needs of cereal consumers worldwide (Abdul et al., 2015). It contains proteins and carbohydrates and provides approximately $72 \%$ of the calories in diets (Guzman et al., 2016). It is cultivated throughout the world; however, the yield varies due to many factors, including biotic and abiotic factors and the unavailability of modern technologies and breeding resources that are required to fight epidemic diseases (Nuttall et al., 2017). One of the major causes of poor yield is stem rust. Stem rust is responsible for loss in grain yields up to $100 \%$ in susceptible wheat varieties and reduces the quality of the grain (Mwando et al., 2012). Stem rust may occur randomly, but it destroys the entire crop once attacked (Afzal et al., 2016).

Puccinia graminis is a fungus that causes stem rust. It belongs to the order Pucciniales (Patpour $\boldsymbol{e t}$ al., 2016). It is a complex and diverse family of pathogens incorporating severe disease symptoms in crop plants. In 1998, a new race, Puccinia graminis $\mathrm{f}$. sp. tritici, commonly known as $U g 99$, was identified as rapidly expanding and destroying cereal crops in Uganda (Ellis et al., 2014). Ug99 starts its life cycle on wheat just after the exposure of spores on wheat plants. These spores are called primary inoculums. The primary or first spore infecting young plants in the early stages is the urediniospore that comes from infected plants grown in previous seasons. Thus, the infected wheat plants serve as a link connecting the generations, which carries Puccinia graminis f. sp. from the harvesting season to the next sown crop (Rodriguez-Algaba et al., 2014).

\section{DEFENSE MECHANISMS AGAINST PUCCINIA GRAMINIS}

Wheat cells contain different organelles that are the main targets of Puccinia graminis. Fungi cannot synthesize their own food so they develop the ability to live on host organisms and use their manufactured food for survival. Puccinia graminis develops a longterm relationship by feeding on the host and thus is called a biotroph. This species absorbs food and nursery molecules from host plants (Olori-Great and Opara, 2017). Wheat is a major host of Puccinia graminis, but before infecting a wheat plant, there is a complex mechanism of interaction or fight between the fungus and host plants. Wheat plants fight to protect their cells and tissues, while the fungus fights for its survival. Wheat has its defense mechanism to prevent complex disease, which consists of three steps. The three steps of defense in plants are usually called the three branches of the innate immune system. As soon as pathogens attack plants, they recognize them as non-self-particles due to the presence of specific cell wall components that are specific only to the microbes that may or may not be pathogens. If the pathogens obtain entry into the inner side of the plant cells and escape the first line of defense, plants respond to the pathogens by secreting pathogen virulence effector proteins that either suppress pathogen growth or kill them directly.

If this second step fails to target pathogens, defensive genes are activated as the third line of defense (Garcion et al., 2014).

\section{PHYSICAL BARRIERS}


The cuticle layer or waxy layer, the cell wall and the stomata act as physical barriers for fungal attack. Closed stomata also inhibit the entry of fungal spores inside the plants (Micali $\boldsymbol{e t}$ al., 2011). These physical barriers protect wheat against fungal diseases. This is the first line of defense against fungi. When the uredospore falls on the surface of the wheat plant, it starts germinating toward the stomata. This germination movement is in the shape of a tube called the germ tube on the surface of the wheat leaf. On reaching a stoma, its tip swells and forms a vesiclelike structure called the appressorium. The protoplasm of the germ tube migrates into the appressorium that is separated by the septum from the germ tube, producing a narrow hypha. It enters inside the substomatal chamber through the stoma. The tip of the hypha again swells and forms a sub-stomatal vesicle. The contents of the appressorium migrate to the vesicle through the hypha. It develops branches and produces hyphae, which spread between the cells (Leonard and Szabo, 2005).

Puccinia graminis must break the first step of defense to come closer to its host. If we could control the stomatal opening and closing, then resistance could be achieved. SNACl and OSSROIc can be engineered to control the closing of the stomata. Resistance can also be achieved by excreting chitinase, which helps to destroy hypha (You et al., 2013). Another path for fungal entry in the plant is via an injury or pre-existing openings on the plant surface. In this situation, the plant must resort to a different set of defense mechanisms, such as toxins and enzymes (Micali et al., 2011).

\section{PLANT IMMUNE SYSTEM}

The second step of defense is the plant's immune system. The plant immune system is different from that of the mammalian, but both share a basic function to recognize and differentiate the cells and molecules of the invading pathogens and their own. This ability to differentiate their own molecules from pathogens is the first step of immune defense. Interaction with conserved molecules or structures accessible to pathogen cells prompts the first level of inducible defenses. Such eliciting molecules are referred as PAMPs or MAMPs (pathogen- or microbe-associated molecular patterns) (Doehlemann and Hemetsberger, 2013; De Wit, 2015). PAMPs work when a plant recognizes a molecule or any activity belonging to a fungus-triggered immune system. This triggered immune system is known as PAMPtriggered immunity (PTI). Different patterns are activated in response to different molecules.

\section{Reactive oxygen species}

The first weapon used by plants is the reactive oxygen species (ROS). Several roles of ROS in plant defense have been proposed. ROS destroy any molecule that comes in contact with them. ROS are used as signaling molecules by wheat (Mittler $\boldsymbol{e t}$ al., 2011). A fungus may avoid this situation by neutralizing the ROS with the help of the Yapl gene (Torres, 2010; Lehmann et al., 2015).

\section{Modifications in the cell wall}

One of the most important responses of PAMPs is the reinforcement of cell wall where the fungus has attacked. The cross-linking of components of the cell wall is ensured by $\mathrm{H}_{2} \mathrm{O}_{2}$ connecting glycoproteins, lignin and suberin (Almagro et al., 2009).

\section{Pathways in signal transduction}

Different plant hormone signaling pathways are regulated by ROS. However, induction of salicylic acid (SA) is one of the best defense signaling pathways, with a well characterized role of regulation through oxidation events and their responses for two main key regulators, TGA transcription factors and NPR1 as a receptor of SA (Fu and Dong, 2013; Shi et al., 2012). SA accumulation occurs on pathogen attack, thus altering the redox state of the cell (Tada et al., 2008). Interestingly, ROS accumulation is not always mediated by induction of SA-dependent defense feedback.

\section{Programmed cell death}

During fungal attack, programmed cell death (PCD) is a resistance mechanism. PCD in plants is well characterized, and many molecular cascades have been described to date, including ROS, $\mathrm{Ca}^{+2}$, nitric oxide (NO) and endoplasmic reticulum (Williams $\boldsymbol{e t}$ al., 2014). In plants, PCD occurs at the time of leaf senescence or photosynthetic reactions and as part of the built-in immune responses initiated by plantpathogen interactions, termed as the hypersensitive response (HR). In specific plant-pathogen interactions, ROS and NO both participate in a coordinated way in planned HR (Bellin et al., 2013).

Much literature has been reviewed that discusses the roles of RNS (reactive nitrogen species) and ROS, as they not only are crucial players during HR but also participate in a multifaceted crosstalk where they can regulate and interact with each other (Wang et al., 2013). However, depending on the biotic interaction, ROS can be directly involved in PCD regulation after induction or might not be involved at all (Torres, 2010). This highlights the fact that $P C D$ is under enigmatic regulation, where ROS have a significant role. Fungi may avoid this situation by neutralizing the ROS with the help of the Yapl gene, which helps to fight the ROS and protects the fungus from severe damage (Lehmann et al., 2015).

\section{Chitinase Activity}


Most importantly, PTI is activated by chitin, which is a key molecule in the fungal cell wall. Different PAMPs, such as chitin, the main component of the Puccinia graminis cell wall, are well recognized by wheat receptor proteins. These receptors trigger the different defense mechanisms to kill the invading pathogen (Gao et al., 2016). CERK1 or CEBiP genes in wheat are reported as a chitin-induced defense and target the cell wall of the fungus (Lee et al., 2014). The fungus avoids damage by targeting chitinase and producing its inhibitors. The Avr4 and Ecp6 genes help the fungus to defend against attack (Van Esse $\boldsymbol{e t}$ al., 2007).

\section{Glucanase Activity}

In addition to chitinase, glucanase is also excreted by wheat cells in response to fungal attack and is reported to inhibit fungi with the help of the GIPI gene (Ekchaweng et al., 2017). The next level of the defense system is highly specific to specific pathogens (Doehlemann and Hemetsberger, 2013) (Table 1).

Table-1: Genes of wheat and fungus involved in defense mechanism

\begin{tabular}{llll}
\hline S. No. & Plant genes activated by PTI & Fungus response (genes) & Stage of Action \\
\hline 1 & ROS & Yapl & Apoplast \\
2 & Chitinase & Ecpl, Avr4 & Apoplast \\
3 & Glucanase & $G I P 1, F B 1$ & Apoplast \\
4 & Stomata Closing & SNAC1, OsSRO1c & Apoplast \\
\hline
\end{tabular}

\section{Jasmonic acid (JA) and Salicylic acid}

Some phytohormones are produced in the immune response, such as jasmonic acid (JA) and salicylic acid, which play a key role in signal transduction pathways. SA and JA are activated for different purposes, but their goal is the same: to protect the plant against pathogens (Glazebrook, 2005). SA in response to any contact of the biotrophic pathogen with the host produces a massive amount of ROS, which induce programmed cell death. Herbivores and necrotic pathogens, by distinction, are proficiently regulated by signaling dependent on JA, resulting in phytoalexins secretion, such as terpenes and flavonoids, which are known to act directly as intruders or toxins (Memelink et al., 2001).

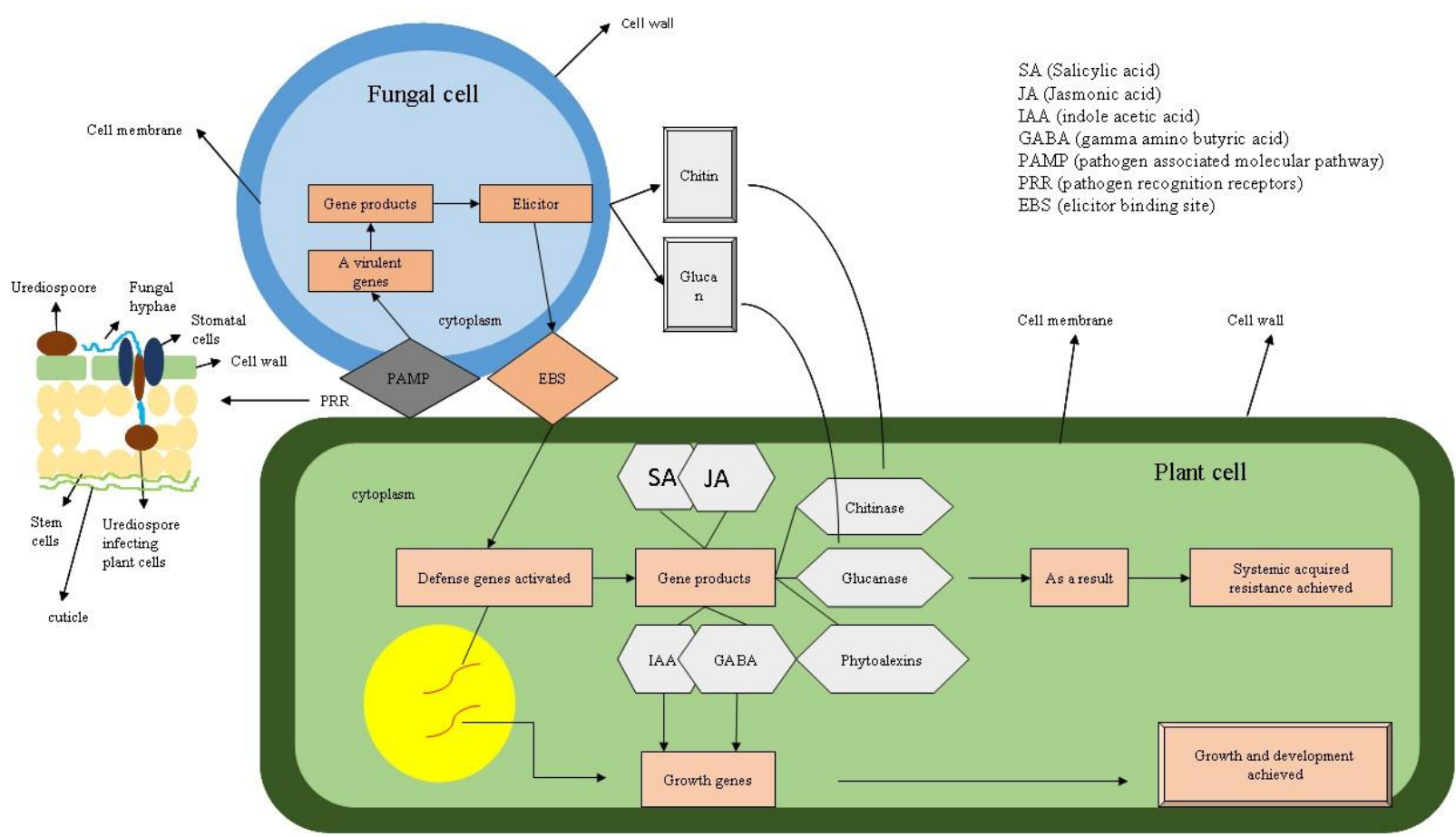

Figure 1: Mechanism of Interaction of Wheat and Fungi

\section{EFFECTOR-TRIGGERED IMMUNITY}

When PTI fails to stop the pathogen from invading, the fungus releases proteins that enter the host cell and prepare it for fungal attack (Hewezi and Baum, 2013). These proteins change the physiology and development of host cells. Effectors are an example of extracellular proteins that perform their function outside the pathogen and in the host. These effectors are highly specific to the pathogen and are important factors to cause disease (Dodds and Rathjen, 2010). Effectors are recognized by the host and activate specific resistance patterns. Wheat has a 
specific hypersensitive response (HR) against Puccinia graminis with the help of $\mathrm{R}$ genes. These $\mathrm{R}$ genes cause host cell death when the pathogen comes in contact with the cell. This response is against the biotrophs, so they could not feed on the host for a longer time. HR is the characteristic defense reaction in effector-triggered immunity (ETI), initiated by the direct or indirect recognition of pathogen proteins called effectors with the help of specific $\mathrm{R}$ proteins of plants. The specificity of $\mathrm{R}$-gene races is a consequence of the specific interaction between $\mathrm{R}$ proteins themselves and highly diverse effectors. This is contrary to the wide-ranging resistance provided by PTI (pattern-triggered immunity) that is induced through the recognition of PAMPs. Unlike effectors, MAMPs are highly conserved between species and races. Although plant immunity has been an interesting field of study, many questions remain unanswered about the molecular mechanisms of resistance, mainly in wheat (Pujol et al., 2016).

\section{$R$ genes and proteins}

$\mathrm{R}$ genes recognize the pathogens and their molecules and interact with them to detoxify or denature. These genes regulate a wide range of defense responses (DR) (Dmochowska-Boguta et al, 2015). Seven wheat defense-associated genes, including TaPIE1, defensin, PR1.2, PR2, PR10, chitinase1 and chitinase2, have been reported in response to pathogen attack (Zhu $\boldsymbol{e t}$ al., 2017). Stem rust-resistant genes have been studied previously, including $S r 13, S r 22, S r 24, S r 25, S r 26, S r 27, S r 28$, Sr32, Sr33, Sr35, Sr36, Sr37, Sr39, Sr40, Sr42, Sr44, and SrTmp (Jin et al., 2007). The effective genes, including SrTmp, Sr22, Sr24, Sr25, Sr26, and Sr36, are dominant in defense responses. The other genes either require a reduction in size in large alien chromosome segments or may lack durability (Jin et al., 2007).

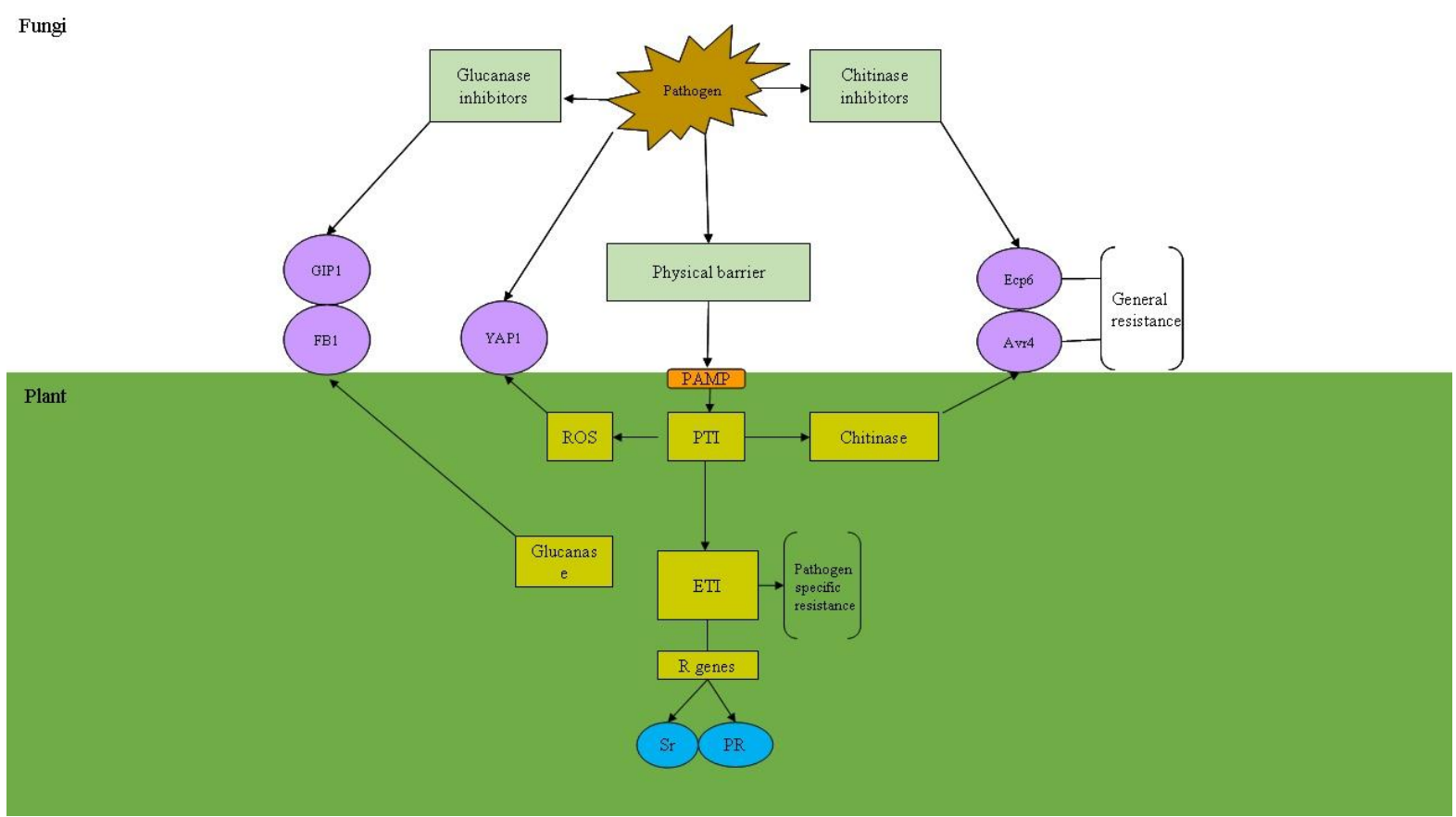

Figure 2: Defense Mechanism of Wheat against Puccinia graminis

\section{PLANT DEFENSE RESPONSE}

Plants are often threatened by a wide range of pathogens, including bacteria, viruses, fungi, and oomycetes. They have evolved an array of response systems to protect themselves from pathogen attack, in which external cues are deciphered and translated into effective defense feedbacks. RLKs (receptor-like kinases) play vital roles in the recognition of outside stimuli and activate defense-associated signaling pathways, thereby regulating cellular responses to pathogen infection (Antolín-Llovera et al., 2012). Regrettably, new rust races are evolving rapidly, reducing the efficiency of major genes and convincing breeders to adopt new resistant sources (Singh $\boldsymbol{e t}$ al., 2011). In addition, minor gene resistance contributes more in durability and precision because such genes are difficult to identify and transfer into corresponding cultivars (Kolmer, 2013). New resistance sources are usually found in the wild relatives, but transferring them to adapted cultivars is problematic and time consuming.

About sixty (60) stem rust resistant genes are identified in wheat up till now (McIntosh et al., 2006). They tolerate stem rust to different extent and to different strains, i.e. $S r 25$ is resistant to $U g 99$ strain (Singh et al., 2011). It is widely being used by the CIMMYT wheat breeding programs. $\mathrm{SrWeb}$ is also 
resistance to $U g 99$ (Hiebert et al., 2010). Sr50 along with other genes like $S r 2$ confers resistance against the disease.

\section{PATHOGENESIS-RELATED GENES}

There are approximately 17 families of pathogenesis-related genes that are activated in plants upon infection by insects or pathogen attack. The first identified family was $P R 1$, which was screened in tobacco plants infected by the tobacco mosaic virus in 1970, showing the symptoms of hypersensitive response (van Loon and van Kammen, 1970). This discovery is considered as a hallmark in the plant defense responses showing hypersensitive responses toward pathogens (Buchel and Linthorst, 1999; van Loon and van Strien, 1999; van Loon et al., 2006). Today, many studies have revealed the multigene families that are responsible for encoding proteins, e.g., PR1 (van Loon et al., 2006; Mitsuhara et al., 2008; Lu et al., 2011). There are other eukaryotes that are known to contain homologues of pathogenesisrelated genes, including humans, animals, insects and fungi. One of the best examples in humans is glioma pathogenesis-related protein (GliPR), associated with cancer development in human cells (Szyperski et al., 1998).

Functional studies of PR genes have enlightened many gene activities that are induced upon invasion, including (i) activation of enzymes involved in oxidative burst, (ii) regulation of enzymes involved in phenylpropanoid pathways, and (iii) triggering of defense-related proteins (Boddu et al., 2007). Similarly, there are many rust-resistant genes found in the wheat cultivars that are concerned with the invading fungus, as the levels of resistance varied by the variation in the structural differentiation of the attacking fungus (Periyannan et al., 2013). Many studies have favored the role of biocontrol agents in imparting resistance to plants by triggering many mechanisms involved in the achievement of systemic resistance, which in turn upregulates the PR genes causing the phytoalexins to accumulate in the infected area (Shoresh et al., 2010).

\section{Pathogenesis-related gene 1 (PR1)}

PR1 proteins in plants are categorized as basic or acidic on the basis of their isoelectric points (van Loon and van Strien, 1999). Various plant species, including tomato, tobacco (Bol and Linthorst, 1990) and barley (Bryngelsson et al., 1994), contain both groups of these proteins. However, antifungal activities are possessed by some PR1 proteins that are basic in nature, e.g., the proteins in tomato named $\mathrm{P} 14 \mathrm{c}$ and those in tobacco named PRIg (Niderman $\boldsymbol{e t}$ al., 1995). The activation of PR1 proteins upon infection and with a hypersensitive response in various tissues of plants also highlights their role in defense-related pathways, but their exact underlying mechanism is still unknown. There is a conserved PR1 domain in all PR1 proteins that is also known as the extracellular SCP-like domain pfam00188. There is a catalytic triad found in human Golgi cells called Golgi-associated pathogenesis-related proteins (GAPR1) in which Ser-73 contacts His-72 and Glu77, forming a dimerized interface (Serrano et al., 2004). There are five assumed active sites in the domain of the PR1 protein, suggesting their enzymerelated functions. However, the functional roles of individual active sites are not yet validated in PR1 proteins.

There are approximately 23 types of $P R I$ such as genes in the hexaploid wheat genome comprising the three main groups of basic, acidic and basic with an extension of the C-terminus, all of which are upregulated upon attack by pathogens (Lu et al., 2011). The role of $P R$ proteins in wheat-performing biochemical as well as defense-related functions toward pathogenesis was also investigated by in vitro analysis (Lu et al., 2011). The basic PRl group was also studied for aspects of characterization and heterologous expression in PR1-1 and PR1-5, also revealing their functions. There are some active sites in the PR1 domain that also contain conserved sequences for the apoptosis process by caspase-like cysteine proteases. This feature is present in both the basic PR proteins existing as monomers, as well as dimers, being resistant (mainly through dimerization) to proteolytic attack. Many functions are associated with PR1 proteins such as their antiviral and antiherbivory nature in tobacco and maize, respectively (Antoniw and White, 1980; Zhang et al., 2015). Moreover, many studies have suggested their role in programmed cell death in affected tissues through protease mediation (Lu et al., 2013). PRl genes are also activated when the fungus $U$. maydis infects the maize plant, repressing the signaling of SA in the early stages of intrusion and enhancing auxin production (Doehlemann et al., 2013).

Genes responsible for encoding PR1 proteins are mainly activated by SA, a defense-related hormone that is also a marker for the plant immune response, providing a wide range of protection against many pathogens. Favorably, there are some MAMPs that trigger the expression of PR genes, especially $P R 1$, being ergosterols in nature (Klemptner et al., 2014). The stability of tobacco is increased toward pathogenic attack by its basic PR1 proteins (transgenically expressed) that make it more resistant to fungal species such as Phytophthora parasitica and Peronospora tabacina. Although the PRl genes have been used as markers in many ways after they were discovered approximately 50 years ago, their exact mode of action is still enigmatic (Van Loon et al., 1970). Recently, a novel feature of $P R l$ has been identified, binding the sterols of invading fungi (Gamir et al., 2017).

Nevertheless, extracellular or vacuolar locations of different PR1 proteins make them effective 
components of basal defense, directly countering pathogens either in the extracellular spaces or upon disruption of host cellular structures during infection. Given their ability to bind sterols, PR1 proteins can potentially affect plant membranes as well. However, plants are most likely to protect themselves from PR1 auto-toxicity by synthesizing these proteins in a pathogen-inducible manner and/or storing them in the vacuole until they are needed. The PR1 proteins of tobacco have a remarkable role in binding the sterols of invading fungi by sequestering them (especially the auxotroph oomycetes) in their membranes (Gamir et al., 2014).

The immune response of PR proteins is more for oomycetes than for Botrytis cinerea and Aspergillus niger. Therefore, it can be deduced that the capability of microbes to produce sterols directly correlates with the antifungal effects of these proteins. The localization of PR1 proteins may be extracellular or intracellular depending on the attack either on the surface of the cell or in the intracellular compartment disruption stage during the infection stage. The vacuolar proteins provide a basal defense against various fungi. To protect themselves from the autotoxicity of the PR proteins, plants have developed a system of producing PRs in vacuoles or in the pathogen-inducible storage manner that is activated only on invasion.

\section{Pathogenesis-related gene 4 (PR-4)/Chitinase}

Plant chitinases can obstruct the growth of fungal hyphae by cleaving the chitin of the fungal cell wall (Grover et al., 2012) and are also known to detach chitin oligomers of the fungal cell wall for the recognition of fungal pathogens. These oligomers are actually MAMPs (microbe-associated molecular patterns) recognized by the membranes of host plants at the point of attack to activate the immune response (Kaku et al., 2006). Several defense reactions are triggered by fungal MAMPs comprising oligosaccharides having chitin in them and contributing in many host species, mainly crops, providing them resistance against a broad range of pathogens. Many responses are triggered by chitin only, including the production of PR proteins named TLPs (thaumatin-like proteins), chitinases and proteases, to initiate the phenylpropanoid pathways involved in plant defense (Boller and Felix, 2009). Many other defense responses, such as the synthesis of $\mathrm{H}_{2} \mathrm{O}_{2}$ and $\mathrm{NO}$ (Zhao et al., 2009), phytoalexin accumulation, octadecanoic pathway of abscisic acid, activation of many TGA, deposition of callose and production of PR proteins, are triggered by chitosan and its fragments (Chujo et al., 2007), including hypersensitive responses upon microbial attack.

Chitinases are reported to have antifungal properties in many plant species. They were first screened in Salanum tuberosum (Stanford et al., 1989), followed by in other plants (Bravo et al.,
2003). The classes were named class I and class II on the presence and absence of the N-terminal cysteine rich domain (sometimes named hevein-like proteins), respectively. Extensive research on class I has revealed that it has a greater affinity to bind chitin and show a strong antifungal response (Odintsova et al., 2007). In any event, class II has been less studied and its functions are also contrary to the former, as its functions vary in accordance with the host species showing divergent biological activities (Bertini et al., 2009). This class is also responsible for various biotic and abiotic stress-induced responses, eventually activating the defense mechanism as well as the regulation of metabolism (Wang et al., 2011).

\section{Pathogenesis-related gene 5 (PR-5; Thaumatin- like proteins)}

Thaumatin-like proteins (TLPs) with a molecular weight of approximately $23 \mathrm{kDa}$ are found in plants, nematodes, arthropods and fungi (Petre et al., 2011). TLPs share sequence similarity with thaumatin, a monomeric sweet-taste protein. TLPs cause inhibition of fungal xylanases and sometimes have weak glucanase activities that are otherwise shown by PR-2 (beta-1,3 glucanase) proteins (Fierens et al., 2007). TLPs have cleft-forming domains in their structure that are acidic in nature and cause deprivation of beta1,3 glucans (glucose polymers) in fungal cell walls (Liu et al., 2010). The expression of TLPs is directly related to fungal attack, so they are called pathogenesis-related type 5 proteins (PR5 proteins) and are mostly studied in plants (Van Loon et al., 2006). However, information about TLPs is increasing.

TLPs are also known to cause autotoxicity in Lentinula edodes (a species of edible mushrooms) by degrading its own cell wall (Sakamoto et al., 2006). Moreover, an interesting feature of Puccinia graminis (wheat stem rust fungus) is the deletion of the Cterminal peptide depriving their TLPs from their typical acidic cleft to form small TLPs of $16-17 \mathrm{kDa}$ (Petre et al., 2011). Extensive studies of fungal genomes have confirmed the presence of TLPs in basidiomycetes. This information supports the fact that TLPs of fungi provide protection and defense against fungal competitors and pathogens. Similarly, MpTLP1 also encodes a gene for glucan synthesis. Fascinatingly, they are also known to show opposite activity by secreting glucanases (Van Loon $\boldsymbol{e t}$ al., 2006).

The genomic studies of defense-coding genes describe the same pathway in all the fungal species involving their secondary metabolism (Dhingra et al., 2013). Stem rust pathogen Puccinia graminis also has a large number of small TLPs (Petre et al., 2011). TLXI is the only small TLP characterized from wheat showing xylanase inhibitor activities (Fierens et al., 2007). Moreover, TLXI from wheat is also capable of binding zymosan (a fungal polysaccharide containing 
glucan) as well as the $\beta$-glucans (Fierens et al., 2007). Plants also produce xylans as the pathogens belonging to GH10 and contribute largely to plant physiology, from the germination of the seed to the ripening of the fruit (Simpson et al., 2002). Simultaneously, plants produce xylanase-inhibiting proteins. Studies have revealed that there are two categories of proteinaceous compounds in cereals, named TAXI and XIP after Triticum aestivum xylanase inhibitor and xylanase inhibitor protein, respectively. They are screened and extracted on the basic of their structure, biochemical roles and genetics. TAXI is known to occur in rye (Secale cereal), durum wheat (Triticum durum), barley (Hordeum vulgare) and common wheat (Triticum aestivum) (Goesaert et al., 2003 and 2004).

\section{Pathogenesis-related gene 10 (PR10)}

PR10, a well-characterized gene, encodes the first enzyme of phenyl propanoid mechanism PAL (phenylalanine ammonia-lyase), an important enzyme in the production of lignin, flavonoids and phenyl propanoids. LTPs (lipid transfer proteins) also play a major role in plant defense as they have antibacterial properties (Boutrot $\boldsymbol{e t}$ al., 2005) and are required in the formation of the mechanical barrier of cutin. Whenever the cell wall or associated membranes are infected by microbial attack, LTPs are required for the repair of damaged tissues. Lignin is a polymer of the cell wall. It is phenolic in chemical nature and linked covalently to hemicellulose and cellulose in the cell wall of plants. It also assists in water and nutrient transport (Tu et al., 2010), strengthening plant immunity. A prominent defense mechanism is carried through lignification in common wheat (Triticum aestivum) to stripe rust causing organism (Puccinia striiformis) f. sp. Tritici (Moldenhauer et al., 2008) and leaf rust (Casassola $\boldsymbol{e t}$ al., 2015).

Many plant species have an inducible response of PR10 genes after microbial invasion. Fungi, bacteria and viruses contribute equally to provoke host plant PR10 genes. While studying the immunocytochemical interaction of Cronartium ribicola (blister rust fungus) with sugar pine needles, it was seen that the cell wall of the attacking fungus was tightly bound by PR10 proteins. Pathogen attack followed by a fungal elicitor or any kind of stress also induces the promoter Ypr10 to regulate GUS activity in young leaves of apple (Malus domestica). PR10 expression is mostly induced while treating a wound. Â-glucuronidase fusion and northern blot analysis of the PR10 promoter confirmed the accumulation of asparagus PR10 proteins after wounding (Liu et al., 2006). Remarkably, PR10 proteins play a vital role not only in plant defense but also in growth and development, as shown by their RNase and ligand binding activities that are triggered on infection. However, studies of the overexpression of PR10 proteins in transgenic plants and their accumulation on interaction with pathogens are still ongoing. The advancements in functional genomics and development in technology can hopefully increase the ability to assess the exact contribution of all the members of the PR10 family in the development of the immune system in plants.

\section{Pathogenesis-related gene 12 (PR12; defensins)}

Defensins, with a length of approximately 45-54 amino acids, are small peptides that are cationic in nature. They have four disulfide bridges that impart stability to their structure, comprised of a dominant alpha-helix and triple stranded beta sheets that are antiparallel, making a cysteine-stabilized alpha-beta motif $(\mathrm{CS} \alpha \beta)$ (Fant et al., 1998). Defensins have a subclass containing five disulfide bonds formed using 10 cysteine residues. The non-covalent (hydrophobic) bonds are replaced by covalent bonds by the fifth disulfide bond that reinforces a hidden hydrogen bond, conferring more thermodynamic stability in defensins compared to other classes (Janssen et al., 2003). This exceptional cysteine pair was screened in two floral defensins named $\mathrm{PhD} 1$ and $\mathrm{PhD} 2$ in Petunia hybrid (Lay et al., 2003). Plant defensins are divided into two classes based on their precursor proteins. A signal sequence and mature defensin domain is found in the first class. This signal is responsible for targeting the protein to the endoplasmic reticulum, where it is ready to enter the secretory pathway after folding. The second group is less common, containing an extra C-terminal prodomain, which is removed proteolytically after or during its passage in the secretory pathway (Lay et al., 2005). This class is well characterized in Petunia hybrida and Nicotiana alata (Lay et al., 2003).

Recently, a subcellular and cytoprotective targeting function was assigned to the prodomain of these defensins (Lay et al., 2014). Plant defensins perform many biological activities in the cell (De Coninck et al., 2013). They are known to obstruct enzyme activities, ion channels and protein synthesis when required. Defensins can also inhibit the proliferative activities of the cancer cells or the action of HIV reverse transcriptase in plants. A large amount of data supports the antifungal activities of the defensins, whereas their antibacterial activities are poorly known (Carvalho and Gomes, 2007). Depending on their target molecules and sub-cellular location, they may perform a similar action in the cell, but their mode of action is quite diverse in each species (Van der Weerden et al., 2010).

Plant defensins, when interacting with their target fungus, either stay at the cell surface from where they send signals to cause cell death, or they are internalized by the fungal cell to interact intracellularly for the death signaling cascade. Cellular uptake is well known for Psd1, MtDef4 (Sagaram et al., 2013) and $\mathrm{NaD1}$ (Van der Weerden et al., 2008), but the latter is found for RsAFP2 (Thevissen et al., 2012). To enter the cell, defensins require a RGFRRR motif, which signals 
their translocation in the fungal cell, and its replacement by RGFRAA or AAAARR stops their ability to enter target fungi (Sagaram et al., 2013). Several mechanisms are established in defensins for their entry in the fungal cell, as this sequence does not exist in all of them. These mechanisms include membrane permeabilization, lipid-assisted pore formation and transient permeabilization of membranes (membrane translocation) and internalization through receptors (Nicolas, 2009). Membrane permeabilization is a conditional mechanism for plant defensins, as it only occurs when a certain concentration is achieved to inhibit fungal growth or its death (Thevissen et al., 2007).

Many plant defensins, such as NaD1, HsAFP1, RsAFP2 and DnAMP1, play a crucial role in fungal cell death in oxidative stress or ROS production (Van der Weerden et al., 2008). However, the antifungal activity of plant defensins is reduced when the ionic strength is increased in the growth medium, preferably by divalent cations. For example, $\mathrm{Mg}^{+2}$ and $\mathrm{Ca}^{+2}$ play a significant role in reducing their efficiency. However, the condition may be contrary depending on the type of defense and the fungus (Spelbrink et al., 2004). Another contrasting mechanism for decreasing the inhibitory activity of defensins through cations is also proposed (Oard and Karki, 2006). Sometimes the structure of defensin is so rigid to interact with the fungal membrane, as in wheat, that the structure of a thionin called $\beta$-purothionin is transformed by magnesium and potassium ions causing the elongation of the alpha-1 helix, unwinding the alpha- 2 helix and changing the loop conformation throughout (Oard and Karki, 2006).

\section{RPG GENE FAMILY}

The RPG gene family provides resistance against Puccinia grraminis $\mathrm{f}$. $\mathrm{sp}$. tririci. The main source of this family is barley. Rpg1, Rpg2, Rpg3 Rpg4, Rpg5, $R p g B H$ and Rpg6 are major members of this family, which provide resistance against Puccinia grraminis. The molecular mechanism of Rpg1, Rpg4 and Rpg5 is unknown.

\section{RPG1}

In 1942, the Rpgl gene was reported for stem rust resistance, and it was used for over 70 years. This gene is located on Chromosome no. $1(7 \mathrm{H})$. Rpgl has homology with the receptor kinase gene. The Rpgl gene has two protein kinase domains, protein kinase 1 (pK1) and protein kinase 2 (pK2). pK1 is a pseudokinase and helps in disease resistance. pK2 is an active domain and performs catalytic activity by phosphorylating proteins. pK1 and $\mathrm{pK} 2$ both are required for sustainable resistance. $\mathrm{pK} 1$ and $\mathrm{pK} 2$ are mostly present in the cell membrane, endomembrane and cytosol. When a pathogen attacks the leaves of a plant, both pK1 and pK2 disappear. This disappearance is due to the phosphorylation reaction, which is essential for sustainable resistance. This phosphorylation reaction starts a few minutes after attack and continues for 20 hours. This reciprocal response plant and stem rust is considered the ETI of the plant defense system.

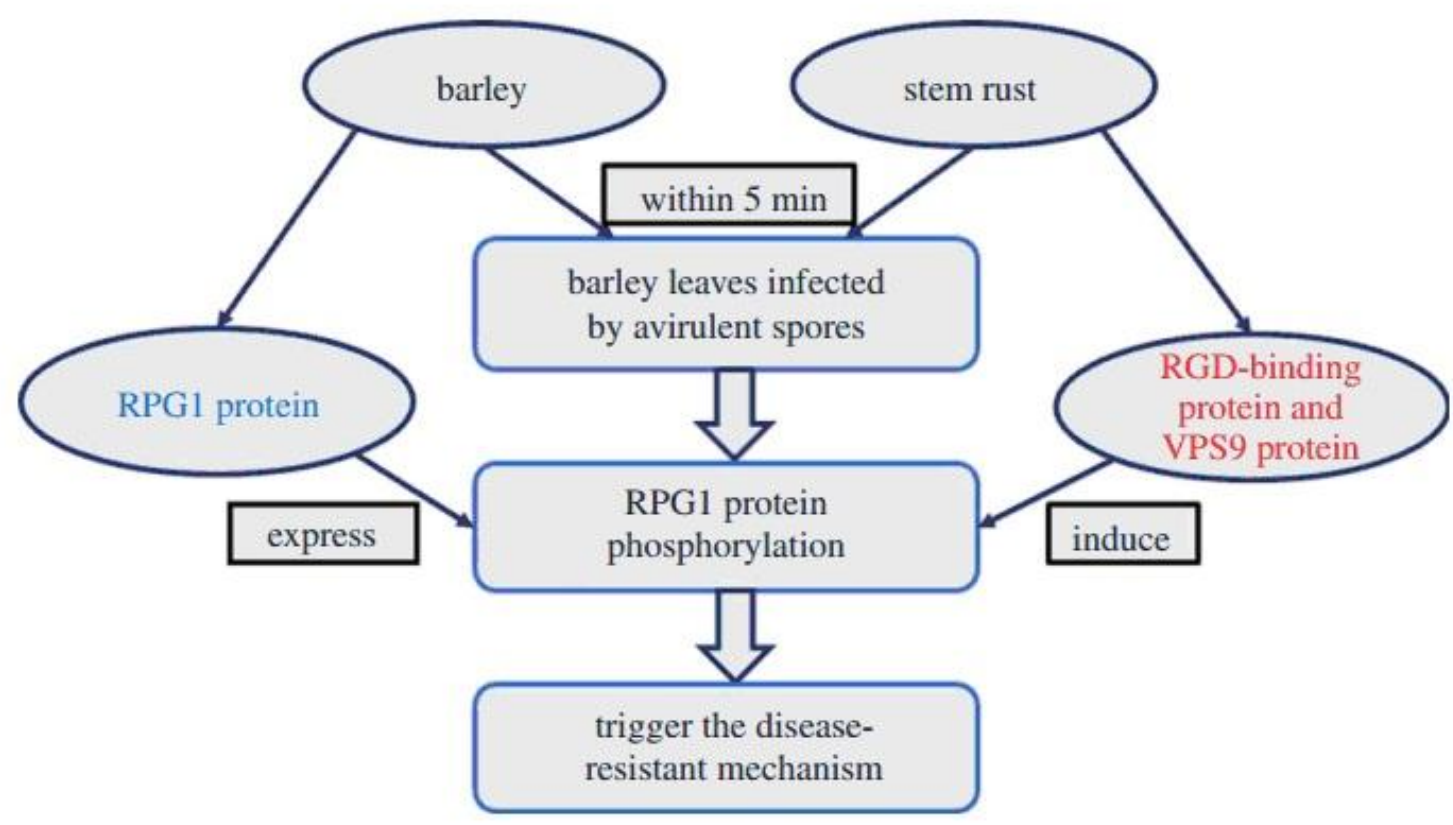

Figure 3: Interaction between RPGlgene and Puccinia graminis, RPG1 protein activate by phosphorylation, $R G D$ binding protein and VPS9 protein are inactive by the same phosphorylation reaction. The activated RPG1 protein further activates race specific defence mechanism such as Sr and PR genes.

\section{RPG4 and 5}


The mapping through RAPD and RFLP markers suggested that Rpg4 is located at the long arm of chromosome 5H (7) (Borokova et al., 1995). Physical mapping suggested that Rpg4/Rpg5 genes are present at the small region of chromosome $5 \mathrm{H}$ (7) (Druka $\boldsymbol{e t}$ al., 2000; Han et al., 1997; Kilian et al., 1997). Rpg4 does not provide resistance independently, but it depends on the product of Rpg5 for its function (Brueggeman et al., 2008). Thus, Rpg5 is the primary source for sustainable resistance against TTKSK and MCCF strains. Rpg4 is a recessive gene, and it depends on temperature, so it has harmful effects on fungi that attack plants. Fungi use the ADF2 protein to absorb the feed from the cytoskeleton. Rpg4 encodes the ADF2 protein that does not respond to the fungus for feeding. However, ADF2 produced by the Rpg4 does not recognize the fungus for this, requiring the product of the Rpg5 gene (Brueggeman et al., 2008). Rpg 4 is also temperature-dependent because its protein is highly sensitive to most proteins. It is suggested that Rpg4 works best at low temperature.

\section{MECHANISM OF SR GENES}

$\mathrm{Sr}$ genes are highly resistant genes and are hostrace-specific. These are not housekeeping genes, so they are only activated when their specific race attacks plants. Race-specific resistant genes are very effective against their specific races, but they are not effective against all races. The race-specific resistance mechanism involves gene to gene interaction. In this mechanism, interaction between specific resistant genes $(R)$ and the pathogen avirulence gene $(A v r)$ is a phenomenon. The $\mathrm{R}$ gene encodes for nucleotide binding and leucine rich repeat (NLR) proteins. These NLRs act as immune receptors to the molecules that are inserted by pathogens in the host cell. These are called effector proteins. This model is also reported and studied in flax rust, but few data are available on stem rust. Wheat stem rust-resistant genes such as Sr22, Sr33, Sr35, Sr45 and Sr50 all encode NLR receptor proteins. $\mathrm{Sr} 33$ and $\mathrm{Sr} 50$ proteins recognize the defense signaling component as the $\mathrm{N}$ terminal coiled-coil domain. Functional studies of Sr33 and Sr50 proteins identified the minimal defense signaling component as the N-terminal coiled-coil domain and showed that dimerization of this domain is required for signaling.

Sr50 and Sr33 actively participate in triggering cell death as well as self-association in plants. Similarly, Sr33 and Sr50 full length proteins mediate a microbe-independent cell death signal in $N$. benthamiana and show self-association responses in plants when they lack a well-recognized avirulence effector. However, as these proteins are auto-active in $N$. benthamiana, it is not clear whether the selfassociation is a preactivated or postactivated event, thus making it possible that self-association of these NLP proteins is initiated through effector recognition. The above statements also support the fact that plant NLR protein oligomerization plays a crucial role in their repression or activation processes. On the other hand, many immune receptors such as RGA4/RGA5 or RPS4/RRS1, Prf RB, RPS5, L6 and N reveal that a self-association platform is provided by their $\mathrm{N}$ terminal domain. A prominent link between CC/TIR self-interaction and the signaling of cell death is observed in RPS4, L6 and MLA10, whereas in the NLR hetero-pairs RGA4/RGA and RPS1/RPS4, hetero-interaction is a contributing factor for the regulation activity of the signaling-proficient NLR partner (Cesari, et al. 2016).

\section{Conclusions}

Stem rust is an important disease of wheat which has potential to damage crop yield significantly if unattended. The present ways to combat this disease are proven to be un-satisfactory and there is a great need to work for the innovative and advanced methods to control the disease.

There are several methods to control stem rust including, chemical control, use of physical barriers, genetic manipulation, etc. However, none is effective against Ug99 strain the causing agent of the disease which is becoming more and more dangerous to the crop worldwide.

There is greater need to understand the mechanism of the disease in host plant and boosting up of the plant defense system by using molecular approaches. This indigenous defense mechanism may enable us to control stem rust.

\section{Acknowledgments}

Financial support by Higher Education Commission of Pakistan is gratefully acknowledged.

\section{References}

Abdul, M., Khan, M., Abdul, R., Muhammad, H., \& MAQSOOD, A. (2015). Identification of leaf rust virulence pattern on wheat germplasm in relation to environmental conditions in Faisalabad. Academia Journal of Agricultural Research, 3(8), 137-155.

Almagro, L., Gómez Ros, L., Belchi-NAVARro, S., Bru, R., Ros Barceló, A., \& Pedreno, M. (2008). Class III peroxidases in plant defence reactions. Journal of experimental botany, 60(2), 377-390.

Antolín-Llovera, M., Ried, M.K., Binder, A. \& PARNISKE, M. (2012) Receptor Kinase Signaling Pathways in Plant-Microbe Interactions. Annual Review of Phytopathology 50, 451-473.

Antoniw, J., \& White, R. (1980). The effects of aspirin and polyacrylic acid on soluble leaf proteins and resistance to virus infection in five cultivars of tobacco. Journal of Phytopathology, 98(4), 331-341. 
Bellin, D., Asai, S., Delledonne, M., \& YoshiokA, H. (2013). Nitric oxide as a mediator for defense responses. Molecular plant-microbe interactions, 26(3), 271-277.

Bellin, D., Delledonne, M., \& VAndelle, E. (2016). Detection of peroxynitrite in plants exposed to bacterial infection Plant Nitric Oxide (pp. 191-200): Springer.

Bertini, L., Caporale, C., Testa, M., Proietti, S. \& CARuso, C. (2009) Structural basis of the antifungal activity of wheat PR4 proteins. FEBS Letters 583, 2865-2871.

Boddu, J., Cho, S. \& Muehlbauer, G.J. (2007) Transcriptome Analysis of Trichothecene-Induced Gene Expression in Barley. Molecular PlantMicrobe Interactions 20, 1364-1375.

Bol, J., LinTHORST, H., \& CORNELISSEN, B. (1990). Plant pathogenesis-related proteins induced by virus infection. Annual review of phytopathology, 28(1), 113-138.

Boller, T. \& FeliX, G. (2009) A Renaissance of Elicitors: Perception of Microbe-Associated Molecular Patterns and Danger Signals by PatternRecognition Receptors. Annual Review of Plant Biology 60, 379-406.

Borovkova, I., StefFenson, B., Jin, Y. A., Rasmussen, J., Kilian, A., Kleinhofs, A., . . . KAO, K. (1995). Identification of molecular markers linked to the stem rust resistance gene rpg4 in barley. Phytopathology (USA).

BOUTROT, F., GUIRAO, A., ALARY, R., JOUDRIER, P. \& GAUTIER, M.F. (2005) Wheat non-specific lipid transfer protein genes display a complex pattern of expression in developing seeds. Biochim Biophys Acta 1730, 114-125.

Bravo, J. M., CAMPO, S., Murillo, I., COCA, M., \& SAN SEGundo, B. (2003). Fungus-and woundinduced accumulation of mRNA containing a class II chitinase of the pathogenesis-related protein 4 (PR-4) family of maize. Plant molecular biology, 52(4), 745-759.

Brueggeman, R., DruKa, A., Nirmala, J., CAVILEer, T., Drader, T., Rostoks, N., . . . KUDRNA, D. (2008). The stem rust resistance gene Rpg5 encodes a protein with nucleotide-bindingsite, leucine-rich, and protein kinase domains. Proceedings of the National Academy of Sciences, 105(39), 14970-14975.

BRYNGELSSON, T., SOMMER-KNUDSEN, J., Gregersen, P., Collinge, D., EK, B., \& ThORDAl-Christensen, H. (1994). Purification, characterization, and molecular cloning of basic PR-1-type pathogenesis-related proteins from barley. Molecular plant-microbe interactions: MPMI, 7(2), 267-275.

BuCHEL S. A. \& LinTHORST H. J. M. (1999). A group plant proteins including upon pathogen infection in parthenogenesis related plants. Edited by Data S. K. and Muthukrishnan S. CRC Press Florida
Casassola, A., Brammer, S.P., Chaves, M.S., Martinelli, J.A., Stefanato, F. \& Boyd, L.A. (2015) Changes in gene expression profiles as they relate to the adult plant leaf rust resistance in the wheat cv. Toropi. Physiological and Molecular Plant Pathology 89, 49-54.

Cesari, S., Moore, J., Chen, C., Webb, D., PERIYANNAN, S., MAgO, R., BERnOUX, M., LAGUdAH, E. \& DodDS, P.N. (2016) Cytosolic activation of cell death and stem rust resistance by wheat MLA-family CC-NLR proteins. Proceedings of the National Academy of Sciences of the United States of America, 6-11.

Chujo, T., TAKaI, R., AKimoto-TomiYama, C., ANDO, S., MinAMI, E., NAGAMURA, Y., KAKU, H., ShibUYa, N., YASUdA, M., NAKASHITA, H., UMEMURA, K., OKADA, A., OKADA, K., NOJIRI, H. \& YAMANE, H. (2007) Involvement of the elicitorinduced gene OsWRKY53 in the expression of defense-related genes in rice. Biochimical et Biophysica Acta - Gene Structure and Expression 1769, 497-505.

De Coninck, B., CAmmue, B.P.A. \& Thevissen, K. (2013) Modes of antifungal action and in planta functions of plant defensins and defensin-like peptides. Fungal Biology Reviews. .

De Oliveira Carvalho, A., \& Gomes, V. M. (2007). Role of plant lipid transfer proteins in plant cell physiology - a concise review. Peptides, 28(5), 1144-1153.

DhINGRA, S., LIND, A.L., LIN, H.C., TANG, Y., RoKAS, A. \& Calvo, A.M. (2013) The Fumagillin Gene Cluster, an Example of Hundreds of Genes under veA Control in Aspergillus fumigatus. PLoS ONE 8.

DMOCHOWSKA-BOGUTA, M., AlabA, S., Yanushevska, Y., Piechota, U., Lasota, E., NADOLSKA-ORCZYK, A., KARLOWSKI, W.M. \& ORCZYK, W. (2015) Pathogen-regulated genes in wheat isogenic lines differing in resistance to brown rust Puccinia triticina. BMC Genomics 16, 742.

DODDS, P.N. \& RATHJEN, J.P. (2010) Plant immunity: towards an integrated view of plant-pathogen interactions. Nature Reviews Genetics 11, 539548.

Doehlemann, G., \& Hemetsberger, C. (2013). Apoplastic immunity and its suppression by filamentous plant pathogens. New Phytologist, 198(4), 1001-1016.

DruKa, A., KudRnA, D., HAN, F., KILIAN, A., SteFFEnson, B., Frisch, D., . . KleINHOFS, A. (2000). Physical mapping of the barley stem rust resistance gene rpg4. Molecular and General Genetics MGG, 264(3), 283-290.

EkChaweng, K., Evangelisti, E., Schornack, S., TIAN, M. \& ChurngChOW, N. (2017) The plant defense and pathogen counterdefense mediated by Hevea brasiliensis serine protease HbSPA and 
Phytophthora palmivora extracellular protease inhibitor PpEPI10. Plos One 12, e0175795.

Ellis, J.G., Lagudah, E.S., SPIELMEYeR, W. \& DoDDS, P.N. (2014) The past, present and future of breeding rust resistant wheat. Frontiers in Plant Science 5.

FANT, F., VRANKen, W., Broekaert, W., \& BorREMANS, F. (1998). Determination of the three-dimensional solution structure of Raphanus sativus Antifungal Protein 1 by $1 \mathrm{H}$ NMR1. Journal of molecular biology, 279(1), 257-270.

FIERENS, E., Rombouts, S., GEBRUERS, K., Goesaert, H., BriJs, K., Beaugrand, J., Volckaert, G., VAn CAMPenhout, S., Proost, P., Courtin, C.M. \& Delcour, J.A. (2007) TLXI, a novel type of xylanase inhibitor from wheat ( Triticum aestivum ) belonging to the thaumatin family. Biochemical Journal 403, 583-591.

FU, Z.Q. \& DONG, X. (2013) Systemic Acquired Resistance: Turning Local Infection into Global Defense. Annual Review of Plant Biology 64, 839863.

GAMIR, J., DARWICHE, R., VAN'T HOF, P., CHOUDHARY, V., STUMPE, M., SCHNEITER, R. \& MAUCH, F. (2017) The sterol-binding activity of PATHOGENESISRELATED PROTEIN 1 reveals the mode of action of an antimicrobial protein. Plant Journal 89, 502-509.

Gamir, J., Pastor, V., Kaever, A., Cerezo, M., \& FLORS, V. (2014). Targeting novel chemical and constitutive primed metabolites against Plectosphaerella cucumerina. The Plant Journal, 78(2), 227-240.

GaO, A.G., HaKimi, S.M., MitTANCK, C.A., WU, Y., WOERnER, B.M., STARK, D.M., SHAH, D.M., LiAnG, J. \& Rommens, C.M.T. (2000) Fungal pathogen protection in potato by expression of a plant defensin peptide. Nature Biotechnology 18, 1307-1310.

GAO, L., WANG, S., ZHANG, Y., LI, X., WANG, H. \& LIU, D. (2016) Identification and characterization of a â-1, 3-glucanase gene, TcLr19Glu, involved in wheat resistance against Puccinia triticina. Journal of Plant Biochemistry and Biotechnology 25, 319-326.

Garcion, C., Lamotte, O., CaCAs, J.L. \& MÉtrauX, J.P. (2014) Mechanisms of Defence to Pathogens: Biochemistry and Physiology. In Induced Resistance for Plant Defense: A Sustainable Approach to Crop Protection pp. 106-136.

GlazeBrooK, J. (2005) Contrasting Mechanisms of Defense Against Biotrophic and Necrotrophic Pathogens. Annual Review of Phytopathology 43, 205-227.

Goesaert, H., Elliott, G., KroOn, P.A., Gebruers, K., Courtin, C.M., Robben, J., Delcour, J.A. \& JugE, N. (2004) Occurrence of proteinaceous endoxylanase inhibitors in cereals. Biochimica et Biophysica Acta - Proteins and Proteomics. .
Goesaert, H., Gebruers, K., Briss, K., Courtin, C.M. \& Delcour, J.A. (2003) XIP-type endoxylanase inhibitors in different cereals. Journal of Cereal Science 38, 317-324.

Grover, A. (2012) Plant Chitinases: Genetic Diversity and Physiological Roles. Critical Reviews in Plant Sciences 31, 57-73.

Guzman, C., Peña, R.J., Singh, R., Autrique, E., Dreisigacker, S., Crossa, J., RutKoski, J., PolAnd, J. \& BATTENFIELD, S. (2016) Wheat quality improvement at CIMMYT and the use of genomic selection on it. Applied and Translational Genomics. .

Han, F., Romagosa, I., Ullrich, S., Jones, B., HAyes, P., \& WesenberG, D. (1997). Molecular marker-assisted selection for malting quality traits in barley. Molecular Breeding, 3(6), 427-437.

HEWEZI, T. \& BAUM, T.J. (2013) Manipulation of Plant Cells by Cyst and Root-Knot Nematode Effectors. Molecular Plant-Microbe Interactions 26, 9-16.

Hiebert, C.W., Thomas, J.B., Mccallum, B.D., Humphreys, D.G., DePaUW, R.M., HaYden, M.J., Mago, R., SchnipPenkoetter, W. \& SPIELMEYER, W. (2010) An introgression on wheat chromosome 4DL in RL6077 (Thatcher*6/PI 250413) confers adult plant resistance to stripe rust and leaf rust (Lr67). Theoretical and Applied Genetics 121, 10831091.

JANSSEN, B. J., SCHIRRA, H. J., LAY, F. T., ANDERSON, M. A., \& CRAIK, D. J. (2003). Structure of Petunia hybrida defensin 1, a novel plant defensin with five disulfide bonds. Biochemistry, 42(27), 82148222.

Jin, Y., Singh, R.P., WARD, R.W., WANYERA, R., Kinyua, M., Nuau, P., Fetch, T., Pretorius, Z. A. \& Yahyaoui, A. (2007) Characterization of Seedling Infection Types and Adult Plant Infection Responses of Monogenic Sr Gene Lines to Race TTKS of Puccinia graminis f. sp. tritici. Plant Disease 91, 1096-1099.

KAKU, H., NishizAWA, Y., ISHII-MINAMI, N., Aкimoto-Tomiyama, C., Dohmae, N., TAKio, K., Minami, E. \& Shibuya, N. (2006) Plant cells recognize chitin fragments for defense signaling through a plasma membrane receptor. Proceedings of the National Academy of Sciences of the United States of America 103, 11086-11091.

Kilian, A., Chen, J., Han, F., Steffenson, B., \& KLEINHOFS, A. (1997). Towards map-based cloning of the barley stem rust resistance genes Rpg1 and rpg4 using rice as an intergenomic cloning vehicle Oryza: From Molecule to Plant (pp. 187-195): Springer.

KLEMPTNER, R. L., SHERWOOD, J. S., TUGIZIMANA, F., DuBERY, I. A., \& PiATER, L. A. (2014). Ergosterol, an orphan fungal microbe-associated molecular pattern (MAMP). Molecular plant pathology, 15(7), 747-761. 
Kolmer, J. (2013) Leaf rust of wheat: Pathogen biology, variation and host resistance. Forests. .

LAy, F. T., Brugliera, F., \& Anderson, M. A. (2003). Isolation and properties of floral defensins from ornamental tobacco and petunia. Plant physiology, 131(3), 1283-1293.

Lay, F. T., Poon, S., Mckenna, J. A., Connelly, A. A., BARbetA, B. L., MCGinNess, B. S., . . HEATH, R. L. (2014). The C-terminal propeptide of a plant defensin confers cytoprotective and subcellular targeting functions. BMC plant biology, 14(1), 41.

LAY, F.T. \& ANDERSON, M. A (2005) Defensins-components of the innate immune system in plants. Current protein \& peptide science 6, 85101.

LEE, W.-S., RudD, J.J., HAMmOND-KosACK, K.E. \& KANYUKA, K. (2014) Mycosphaerella graminicola LysM Effector-Mediated Stealth Pathogenesis Subverts Recognition Through Both CERK1 and CEBiP Homologues in Wheat. Molecular PlantMicrobe Interactions 27, 236-243.

LEHMANN, S., SERRANO, M., L'HARIDON, F., TJAmos, S.E. \& METRAUX, J.P. (2015) Reactive oxygen species and plant resistance to fungal pathogens. Phytochemistry. .

LEONARD, K.J. \& SzABO, L.J. (2005) Stem rust of small grains and grasses caused by Puccinia graminis. Molecular Plant Pathology 6, 99-111.

LiaO, Y.W.K., ShI, K., FU, L.J., ZhanG, S., Li, X., DONG, D.K., JiANG, Y.P., ZHOU, Y.H., XIA, X.J., LIANG, W.S. \& YU, J.Q. (2012) The reduction of reactive oxygen species formation by mitochondrial alternative respiration in tomato basal defense against TMV infection. Planta 235 , 225-238.

Liu, X., Huang, B., Lin, J., Fei, J., Chen, Z., PAng, Y., . . TANG, K. (2006). A novel pathogenesisrelated protein (SsPR10) from Solanum surattense with ribonucleolytic and antimicrobial activity is stress-and pathogen-inducible. Journal of plant physiology, 163(5), 546-556.

LiU, X., Williams, C.E., Nemacheck, J.A., Wang, H., Subramanyam, S., ZHENG, C. \& CHEN, M.-S. (2010) Reactive Oxygen Species Are Involved in Plant Defense against a Gall Midge. Plant Physiol 152, 985-999.

LU, S., FARIS, J.D., SHERWOOD, R. \& EDWARDS, M.C. (2013) Dimerization and protease resistance: New insight into the function of PR-1. Journal of Plant Physiology 170, 105-110.

LU, S., FRIESEN, T.L. \& FARIS, J.D. (2011) Molecular characterization and genomic mapping of the pathogenesis-related protein 1 (PR-1) gene family in hexaploid wheat (Triticum aestivum L.). Molecular genetics and genomics: MGG $\mathbf{2 8 5}$, 485-503.

Mcintosh, R. A., Wellings, C. R., \& PARK, R. F. (1995). Wheat rusts: an atlas of resistance genes: Csiro Publishing.
MEMElinK, J., Verpoorte, R. \& KiJne, J.W. (2001) ORCAnization of jasmonate-responsive gene expression in alkaloid metabolism. Trends in Plant Science. .

Micali, C.O., Neumann, U., Grunewald, D., PANSTRUGA, R. \& O\&APOS;CONNELL, R. (2011) Biogenesis of a specialized plant-fungal interface during host cell internalization of Golovinomyces orontii haustoria. Cellular Microbiology 13, 210226.

Mitsuhara, I., Iwai, T., SeO, S., Yanagawa, Y., Kawahigasi, H., Hirose, S., OHKawa, Y. \& OHASHI, Y. (2008) Characteristic expression of twelve rice PR1 family genes in response to pathogen infection, wounding, and defense-related signal compounds (121/180). Molecular Genetics and Genomics 279, 415-427.

Mittler, R., VANDERAuWERA, S., SuZuki, N., Miller, G., Tognetti, V.B., VAndepoele, K., Gollery, M., ShulaeV, V. \& VAN BREUSEGEM, F. (2011) ROS signaling: The new wave? Trends in Plant Science.

MoldenhaUer, J., PRETORIUS, Z.A., MOERschbacher, B.M., Prins, R. \& VAN DER WESTHUIZEN, A.J. (2008) Histopathology and PRprotein markers provide insight into adult plant resistance to stripe rust of wheat. Molecular Plant Pathology 9, 137-145.

Mwando, K., TABU, I., OTAYE, O., \& NJAU, P. (2012). Effect of stem rust on the quality of selected barley genotypes. ISRN Agronomy, 2012.

NiCOLAS, P. (2009). Multifunctional host defense peptides: intracellular-targeting antimicrobial peptides. The FEBS journal, 276(22), 6483-6496.

Niderman, T., Genetet, I., BRUYere, T., GeES, R., Stintzi, A., Legrand, M., . . . Mosinger, E. (1995). Pathogenesis-related PR-1 proteins are antifungal (isolation and characterization of three 14-kilodalton proteins of tomato and of a basic PR1 of tobacco with inhibitory activity against Phytophthora infestans). Plant physiology, 108(1), 17-27.

NutTAll, J.G., O’LEARY, G.J., PANOZZO, J.F., WALKER, C.K., BARLOW, K.M. \& FITZGERALD, G.J. (2017) Models of grain quality in wheat-A review. Field Crops Research 202, 136-145.

OARD, S. \& KARKI, B. (2006) Mechanism of betapurothionin antimicrobial peptide inhibition by metal ions: molecular dynamics simulation study. Biophysical Chemistry 121, 30-43.

OdintSOVA, T. I., VASSILEVSKI, A. A., Slavokhotova, A. A., Musolyamov, A. K., FinkinA, E. I., KhadeEVA, N. V., . . . Grishin, E. V. (2009). A novel antifungal hevein-type peptide from Triticum kiharae seeds with a unique 10cysteine motif. The FEBS journal, 276(15), 42664275.

OlORI-GREAT, N. G., \& OpARA, E. U. (2017). Defence Mechanisms in Plants Against Invading Plant 
Pathogenic Microbes in Nigeria. Journal of Agriculture and Sustainability, 10(1).

Patpour, M., Hovmøller, M.S., Justesen, A.F., NeWCOMB, M., OLIVERA, P., Jin, Y., SZABO, L.J., Hodson, D., Shahin, A.A., WANYERA, R., HABARUREMA, I. \& WobIBI, I. (2016) Emergence of Virulence to SrTmp in the Ug99 Race Group of Wheat Stem Rust, Puccinia graminis f . sp . tritici , in Africa. Plant Disease. .

Periyannan, S., Moore, J., Ayliffe, M., Bansal, U., Wang, X., Huang, L., Deal, K., LuO, M., KonG, X., BARIANA, H., MAGO, R., MCINTOSH, R., DodDs, P., DVOrAK, J. \& LAGUdAH, E. (2013) The Gene Sr33, an Ortholog of Barley Mla Genes, Encodes Resistance to Wheat Stem Rust Race Ug99. Science 341, 786-788.

Petre, B., Major, I., Rouhier, N. \& Duplessis, S. (2011) Genome-wide analysis of eukaryote thaumatin-like proteins (TLPs) with an emphasis on poplar. BMC Plant Biology 11, 33.

Pujol, V., ROBLES, J., WANG, P., TAYLOR, J., ZHANG, P., HuAnG, L., TABE, L. \& Lagudah, E. (2016) Cellular and molecular characterization of a stem rust resistance locus on wheat chromosome 7AL. BMC Research Notes 9, 502.

Rodriguez-Algaba, J., WAlter, S., Sørensen, C.K., Hovmøller, M.S. \& Justesen, A.F. (2014) Sexual structures and recombination of the wheat rust fungus Puccinia striiformis on Berberis vulgaris. Fungal Genetics and Biology 70, 77-85.

SAGARAM, U.S., El-Mounadi, K., BuchKo, G.W., BERG, H.R., KAUR, J., PANDURANGI, R.S., SMITH, T.J. \& SHAH, D.M. (2013) Structural and functional studies of a phosphatidic acid-binding antifungal plant defensin MtDef4: Identification of an RGFRRR motif governing fungal cell entry. PLOS ONE 8.

SAKAMOto, Y., WATANABE, H., NAGaI, M., NAKADE, K., TAKAHASHI, M., \& SATO, T. (2006). Lentinula edodes tlg1 encodes a thaumatin-like protein that is involved in lentinan degradation and fruiting body senescence. Plant physiology, 141(2), 793801.

Serrano, R. L., Kuhn, A., Hendricks, A., Helms, J. B., Sinning, I., \& Groves, M. R. (2004). Structural analysis of the human Golgi-associated plant pathogenesis related protein GAPR-1 implicates dimerization as a regulatory mechanism. Journal of molecular biology, 339(1), 173-183.

ShI, K., FU, L.-J., Zhang, S., LI, X., DONG, D.-K., JIANG, Y.-P., . . Y YU, J.-Q. (2012). The reduction of reactive oxygen species formation by mitochondrial alternative respiration in tomato basal defense against TMV infection. Planta, 235(2), 225-238.

SHORESH, M., HARMAN, G.E. \& MASTOURI, F. (2010) Induced Systemic Resistance and Plant Responses to Fungal Biocontrol Agents. Annual Review of Phytopathology 48, 21-43.
Simpson, P. J., Jamieson, S. J., AbOU-HaChem, M., Karlsson, E. N., Gilbert, H. J., Holst, O., \& WILLIAMSON, M. P. (2002). The solution structure of the CBM4-2 carbohydrate binding module from a thermostable Rhodothermus marinus xylanase. Biochemistry, 41(18), 5712-5719.

SingH, R.P., HODSON, D.P., HuERTA-ESPINO, J., JIN, Y., Bhavani, S., NuAU, P., Herrera-Foessel, S., SingH, P.K., SingH, S. \& GovindAN, V. (2011) The Emergence of Ug99 Races of the Stem Rust Fungus is a Threat to World Wheat Production. Annual Review of Phytopathology 49, 465-481.

Spelbrink, R. G., DilmaC, N., Allen, A., Smith, T. J., SHAH, D. M., \& Hockerman, G. H. (2004). Differential antifungal and calcium channelblocking activity among structurally related plant defensins. Plant physiology, 135(4), 2055-2067.

StAnford, A., BeVAn, M., \& NorthCOTE, D. (1989). Differential expression within a family of novel wound-induced genes in potato. Molecular and General Genetics MGG, 215(2), 200-208.

Szyperski, T., FernandeZ, C., Mumenthaler, C., \& WÜTHRICH, K. (1998). Structure comparison of human glioma pathogenesis-related protein GliPR and the plant pathogenesis-related protein P14a indicates a functional link between the human immune system and a plant defense system. Proceedings of the National Academy of Sciences, 95(5), 2262-2266.

TADA, Y., SPOEL, S.H., PAJEROWSKa-MuKhtar, K., Mou, Z., Song, J., WANG, C., ZuO, J. \& Dong, X. (2008) Plant Immunity Requires Conformational Charges of NPR1 via S-Nitrosylation and Thioredoxins. Science 321, 952-956.

Thevissen, K., De Mello Tavares, P., Xu, D., BLANKENSHIP, J., VANDENBOSCH, D., IDKOWIAKBALDYS, J., . . DE GROOT, P. W. (2012). The plant defensin RsAFP2 induces cell wall stress, septin mislocalization and accumulation of ceramides in Candida albicans. Molecular microbiology, 84(1), 166-180.

Thevissen, K., GhazI, A., De Samblanx, G. W., BrownleE, C., Osborn, R. W., \& BroEKAERT, W. F. (1996). Fungal membrane responses induced by plant defensins and thionins. Journal of Biological Chemistry, 271(25), 15018-15025.

TORRES, M.A. (2010) ROS in biotic interactions. Physiologia Plantarum, 138(4), 414-429.

TU, Y., ROCHFORT, S., LIU, Z., RAN, Y., GRIFFITH, M., BADENhORST, P., LOUIE, G. V, BOWMAN, M.E., SMITH, K.F., NoEl, J.P., Mouradov, A. \& SPANGENBERG, G. (2010) Functional analyses of caffeic acid O-Methyltransferase and CinnamoylCoA-reductase genes from perennial ryegrass (Lolium perenne). The Plant cell 22, 3357-3373.

VAN DeR WeERden, N. L., HANCOCK, R. E., \& ANDERSON, M. A. (2010). Permeabilization of fungal hyphae by the plant defensin NaD1 occurs through a cell wall dependent process. Journal of Biological Chemistry, jbc. M110. 134882. 
VAn Esse, H. P., Bolton, M. D., Stergiopoulos, I., DE WIT, P. J., \& ThOMMA, B. P. (2007). The chitinbinding Cladosporium fulvum effector protein Avr4 is a virulence factor. Molecular PlantMicrobe Interactions, 20(9), 1092-1101.

VAN LOON, L., \& VAN KAMMEN, A. (1970). Polyacrylamide disc electrophoresis of the soluble leaf proteins from Nicotiana tabacum var. 'Samsun'and 'Samsun NN': II. Changes in protein constitution after infection with tobacco mosaic virus. Virology, 40(2), 199-211.

VAN LOON, L., \& VAN STRIEN, E. (1999). The families of pathogenesis-related proteins, their activities, and comparative analysis of PR-1 type proteins. Physiological and molecular plant pathology, 55(2), 85-97.

VAN LOON, L.C., REP, M. \& PIETERSE, C.M.J. (2006) Significance of Inducible Defense-related Proteins in Infected Plants. Annual Review of Phytopathology 44, 135-162.

VRIENS, K., CAMMUE, B.P.A. \& THEVISSEN, K. (2014) Antifungal plant defensins: Mechanisms of action and production. Molecules.

WANG, B., YU, J., ZHU, D. \& ZHAO, Q. (2013) Maize defensin $\mathrm{ZmDEF} 1$ is involved in plant response to fungal phytopathogens. African Journal of Biotechnology.

Http://www.ajol.info/index.php/ajb/article/view/9 7628.

WANG, N., XIAO, B. \& XIONG, L. (2011) Identification of a cluster of PR4-like genes involved in stress responses in rice. Journal of Plant Physiology 168, 2212-2224.

WANG, Y., LIN, A., LoAKE, G.J. \& ChU, C. (2013) $\mathrm{H} 2 \mathrm{O} 2$-induced leaf cell death and the crosstalk of reactive nitric/oxygen species. Journal of Integrative Plant Biology. .

WILLIAMS, B., VERCHOT, J. \& DICKMAN, M.B. (2014) When supply does not meet demand-ER stress and plant programmed cell death. Frontiers in Plant Science 5.

You, J., Zong, W., LI, X., Ning, J., Hu, H., LI, X., XIONG, L. (2012). The SNAC1-targeted gene OsSRO1c modulates stomatal closure and oxidative stress tolerance by regulating hydrogen peroxide in rice. Journal of Experimental Botany, 64(2), 569-583.

ZHAO, M.-G., CHEN, L., ZHANG, L.-L. \& ZHANG, W.H. (2009) Nitric Reductase-Dependent Nitric Oxide Production Is Involved in Cold Acclimation and Freezing Tolerance in Arabidopsis. PLANT PHYSIOLOGY 151, 755-767.

Zhu, X., Lu, C., Du, L., Ye, X., LIU, X., COUles, A. \& ZHANG, Z. (2017) The wheat NB-LRR gene TaRCR1 is required for host defence response to the necrotrophic fungal pathogen Rhizoctonia cerealis. Plant Biotechnology Journal 15, 674687.

\section{Figure Legends}

Figure 1: Mechanism of interaction of wheat and fungi Figure 2: Defense mechanism of wheat against Puccinia graminis

Figure 3: Interaction between RPG1gene and Puccinia graminis, RPG1 protein activate by phosphorylation, RGD binding protein and VPS9 protein are inactive by the same phosphorylation reaction. The activated RPG1 protein further activates race specific defence mechanism such as $\mathrm{Sr}$ and $\mathrm{PR}$ genes. 